\title{
In vitro virulence evaluation of clinical and environmental isolates of dermatophyte
}

\section{fungi}

\author{
Avaliação da virulência in vitro de isolados clínicos e ambientais de fungos dermatófitos \\ Evaluación de la virulencia in vitro de aislados clínicos y ambientales de hongos dermatofitos
}

\begin{abstract}
Dermatophytes are keratinophilic fungi and the causative agent of dermatophytosis in animals and people. In the pathogenesis of this disease, enzymes such as DNase, gelatinase, lipase, keratinase, elastase, and collagenase are highlighted. This work aimed to verify the production of these enzymes by clinical and environmental isolates of dermatophytes. Environmental strains were obtained by the Vanbreuseghem technique (1952), using soil samples from different Brazilian locations. The clinical samples were obtained from animal hair and crust sent to the Veterinary Microbiological Diagnostic Service/UFRRJ. The enzymatic evaluation of the dermatophytes was made by spectrophotometer absorbance readings (collagenase, elastase, and keratinase), degradation halo formation in Petri dishes (DNase and lipase) and tube liquefaction (gelatinase). The clinical isolates were Microsporum canis (11), Nannizzia gypsea (7), N. nana (2), Trichophyton mentagrophytes (4) and Trichophyton sp. (6). The environmental isolates were $N$. gypsea (25), N. nana (1) and Trichophyton sp. (4). There was no statistically significant difference in keratinase, elastase, lipase and gelatinase production between the clinical and environmental isolates groups. There was a statistically significant difference in collagenase and DNase production. It is concluded that both clinical and soil samples are capable of producing enzymes related to dermatophyte infection.
\end{abstract}

Keywords: Dermatophytosis; Dermatopathy; Tinea; Pathogenicity; Environmental mycology. 


\begin{abstract}
Resumo
Os dermatófitos são fungos queratinofílicos relacionados a dermatofitoses em animais e pessoas. Na patogenia desta doença, destacam-se enzimas como DNase, gelatinase, lipase, queratinase, elastase e colagenase. Neste trabalho, objetivou-se verificar a produção destas enzimas por isolados clínicos e ambientais de dermatófitos. As cepas ambientais foram obtidas pela técnica de Vanbreuseghem (1952), utilizando amostras de solo de diferentes localidades do Brasil. As amostras clínicas foram oriundas de pelos e crostas de animais enviadas ao Serviço de Diagnóstico Microbiológico Veterinário/UFRRJ. A avaliação enzimática dos dermatófitos foi feita por leituras de absorbância em espectrofotômetro (colagenase, elastase e queratinase), formação de halo de degradação em placas (DNase e lipase) e liquefação em tubos (gelatinase). Os isolados clínicos foram Microsporum canis (11), Nannizzia gypsea (7), N. nana (2), Trichophyton mentagrophytes (4) e Trichophyton spp. (6). Os isolados ambientais foram $N$. gypsea (25), N. nana (1) e Trichophyton spp. (4). Não houve diferença estatística significativa na produção de queratinase, elastase, lipase e gelatinase entre os grupos de isolados clínicos e ambientais. Houve diferença significativa estatisticamente na produção de colagenase e DNase. Conclui-se que tanto os dermatófitos oriundos de amostras clínicas de animais, quanto os do solo são capazes de produzir enzimas relacionadas à infecção dermatofítica.
\end{abstract}

Palavras-chave: Dermatofitose; Dermatopatia; Tinea; Patogenicidade; Micologia ambiental.

\begin{abstract}
Resumen
Los dermatofitos son hongos queratinofílicos relacionados con las dermatofitosis en animales y personas. En la patogenia de esta enfermedad destacan enzimas como DNasa, gelatinasa, lipasa, queratinasa, elastasa y colagenasa. En este trabajo, el objetivo fue verificar la producción de estas enzimas por aislamientos clínicos y ambientales de dermatofitos. Las cepas ambientales se obtuvieron mediante la técnica de Vanbreuseghem (1952), utilizando muestras de suelo de diferentes lugares de Brasil. Las muestras clínicas proceden de pelos y costras de animales remitidas al Servicio de Diagnóstico Microbiológico Veterinario / UFRRJ. La evaluación enzimática de los dermatofitos se realizó mediante lecturas de absorbancia en un espectrofotómetro (colagenasa, elastasa y queratinasa), formación de un halo de degradación en placa (DNasa y lipasa) y licuefacción en tubos (gelatinasa). Los aislamientos clínicos fueron Microsporum canis (11), Nannizzia gypsea (7), N. nana (2), Trichophyton mentagrophytes (4) y Trichophyton spp. (6). Los aislamientos ambientales fueron $N$. gypsea (25), N. nana (1) y Trichophyton spp. (4). No hubo diferencias estadísticamente significativas en la producción de queratinasa, elastasa, lipasa y gelatinasa entre los grupos de aislados clínicos y ambientales. Hubo una diferencia estadísticamente significativa en la producción de colagenasa y DNasa. Se concluye que tanto los dermatofitos de muestras clínicas de animales como los del suelo son capaces de producir enzimas relacionadas con la infección por dermatofitos.
\end{abstract}

Palabras clave: Dermatofitosis; Dermatopatía; Tinea; Patogenicidad; Micología ambiental.

\title{
1. Introduction
}

Dermatophytes are keratinophilic fungi widely distributed in the environment and keratinized structures of living beings. Due to these characteristics, they are apt for the development of dermatophytosis, a highly contagious zoonosis of great occurrence in the veterinary and human medical clinic (Koneman \& Allen, 2008; Pontes et al., 2013; Taghipour et al., 2021).

The species Microsporum canis, Trichophyton mentagrophytes var. mentagrophytes, T. verrucosum, Nannizzia. gypsea and $N$. nana are the main causative agents related to animal cases. The latter two are classified as geophilic and easily isolated from soil samples. Animals and humans can acquire dermatophytosis when they come into direct contact with the soil, or other reservoirs where structures of these fungi can be found. The acquisition can additionally occur by contact with another animal, or infected person (Markey et al., 2013; Long et al., 2020).

The ability to install and invade portions of keratinized tissues related to the enzyme production by the fungi. Naturally, there are variations in the quantity and specificity of enzymes produced in different situations, such as dermatophytes isolated from the soil, asymptomatic and symptomatic animals, with differences between the stages of the disease (Vermout et al., 2008; Sharma et al., 2012; Uribe \& Cardona-Castro, 2013). So, one of the possibilities to inhibit dermatophytosis would be by controlling the enzymes produced by the fungi (Meevootison \& Niederpruem, 1979).

Thus, researches have been carried out to better understand the role of enzymatic virulence factors, characterizing the pathogenicity of dermatophytes and the pathogenesis of dermatophytosis. Among these studies, keratinase, elastase, collagenase, lipase, gelatinase are the enzymes most evaluated. Little data is available about DNase (Viani et al., 2001; da 
Silva et al., 2005; Giudice et al., 2012; Kaplan et al., 2020).

Keratinase, an enzyme that stands out in research, acts on keratin, a substrate that defines the group to which these fungi belong. The action of keratinase cleaves disulfide bonds of larger portions of keratin, generating peptides and amino acids capable of meeting the fungi metabolic requirements. Thus, this enzyme is a primary factor in the early stages of dermatophytosis (Monodi, 2008; Vermout et al., 2008; Cortezi, 2009).

The elastase production has been related to the intensity of inflammatory reactions and the occurrence of lesions in people, rabbits, and other animals, acting on elastin, another constituent of the skin and deeper structures of the organism, such as vessels and ligaments (Rippon \& Varadi, 1968; López-Martínez et al., 1994; Cafarchia et al., 2012).

Collagen is one of the most abundant elements in living organisms, constituting the extracellular matrix. There are several types of collagen in the body. Type I is presented in the skin, tendons, and bones, being of greater importance in the pathogenesis of dermatophytes. There are few studies that seek the production of collagenase by fungi. Most of them evaluate gelatin degradation, a product of partial hydrolysis of collagen (Rippon, 1968; Ibrahim-Granet et al., 1996; Viani et al., 2007).

Gelatin, a product of partial collagen hydrolysis, is present in large quantities in the body of animals and people. Compared to other fungi groups, dermatophytes are strong gelatinase producers, which may also be an enzyme that characterizes the group (Sharma et al., 2017).

Deoxyribonuclease (DNase) is the enzyme responsible for cleaving the phosphodiester bonds presented in the DNA molecule. In humans, the production of DNase by dermatophytes is directly proportional to the intensity of the patient's inflammatory response, and there are few details about its role, especially in animals (Viani et al., 2001; Cafarchia et al., 2012).

Another important enzyme in the early stages of dermatophytosis is lipase. The surface of the keratinized tissues has a lipid layer, which the fungi must overcome to access the sources of keratin. Although it is produced by practically all dermatophytes, the straight correlation between lipase production and the appearance of lesions is not described, being produced by fungi isolated from symptomatic and asymptomatic patients, as well as environmental ones (Hellgrem \& Vincent, 1981; Viani et al., 2001; Cafarchia et al. 2012; Elavarashi et al., 2017).

Thus, better understanding the action and capacity of clinical or environmental dermatophytes to produce these virulence factors can help to elucidate the mechanisms behind human and animal clinical cases. Such information can impact the prevention, control, and treatment of these important infectious diseases, also helping to better understand the fungi's survival on the environment.

\section{Methodology}

The present research was approved by the Ethics Committee on the Use of Animals (CEUA) of the Veterinary Institute of UFRRJ under the protocol no 1395270617.

A total of 30 clinical isolates were used in the present study. These isolates were obtained between November 2016 and September 2018, from clinical samples (hair and crusts) from dogs, cats, rabbits, and guinea pigs brought to the Veterinary Hospital of UFRRJ. The isolates were obtained on Selective Agar for Pathogenic Fungi ${ }^{\circledR}$ (Merck ${ }^{\circledR}$, Germany), after incubation at $25^{\circ} \mathrm{C}$ for up to 30 days.

The dermatophyte isolates from the soil were obtained based on the technique described by the Vanbreuseguem (1952). Soil samples were placed, covering the bottom of sterile Petri dishes (100 x $15 \mathrm{~mm})$, mixed with sterile horsehair, that served as a substrate for the dermatophytes, and moistened with sterile distilled water. Colonies appeared within 15 days after incubation at $25{ }^{\circ} \mathrm{C}$. The soil samples were taken from different locations in Brazil, preferably from places where animals could be found, such as parks, squares, gardens, and livestock fields.

Dermatophytes were identified by macroscopic and microscopic evaluation, following the classification proposed by 
De Hoog et al. (2000/2017), and the Atlas of Clinical Fungi (online version). By that, it was possible to identify Microsporum canis (11), Nannizzia gypsea (7), N. nana (2), Trichophyton mentagrophytes (4) and Trichophyton spp. (6), between the clinical samples. From the 30 soil samples, N. gypsea (25), N. nana (1), and Trichophyton spp. (4) were recovered. All isolates were kept in Fungobiotic ${ }^{\circledR}$ Agar (HiMedia ${ }^{\circledR}$, India) during the experiment being reactivated seven days before each enzyme production test on Sabouraud Dextrose Agar (HiMedia ${ }^{\circledR}$, India) at $25^{\circ} \mathrm{C}$.

For techniques that require absorbance reading on a spectrophotometer (keratinase, elastase, and collagenase), each fungus was previously inoculated in $5 \mathrm{ml}$ of Sabouraud Dextrose broth (HiMedia ${ }^{\circledR}$, India), followed by incubation at $25^{\circ} \mathrm{C}$ for 15 days, without shaking. Afterward, $500 \mu 1$ of a solution containing $10^{6}$ fungal structures (counted in a Neubauer chamber) were transferred to $50 \mathrm{ml}$ of a base medium (1000 ml distilled water; $6 \mathrm{~g} \mathrm{MgSO}_{4} ; 1 \mathrm{ml}$ Protovit $^{\circledR} ; 0.111 \mathrm{~g} \mathrm{CaCl}_{2}$ ) added with 3 g powdered bovine horn (keratinase), $3 \mathrm{~g}$ elastin (elastase), or $3 \mathrm{~g}$ type I collagen (SIGMA ${ }^{\circledR}$ ) (Siesenop \& Böhm, 1995). The added substrates worked as the only nitrogen and carbon source in the culture medium, promoting the production of the target enzymes. The tests were incubated at $25^{\circ} \mathrm{C}$ for 14 days without shaking nor lighting.

To evaluate the keratinase production, the tubes were centrifuged at 6,000 rpm for $10 \mathrm{~min}$, and $1 \mathrm{ml}$ of the supernatant were mixed with $2 \mathrm{ml}$ of $200 \mathrm{mM}$ tris- $\mathrm{HCl}$ solution, $100 \mathrm{mM} \mathrm{CaCl}_{2}$ (pH 8.0), and $10 \mathrm{mg}$ of Keratin Azure (SIGMA ${ }^{\circledR}$ ), followed by $24 \mathrm{~h}$ incubation in the water bath at $37{ }^{\circ} \mathrm{C}$ without shaking, and centrifugation at 6,000 rpm for $10 \mathrm{~min}$ (Viani et al., 2001; da Silva et al., 2005). The keratin degradation was quantified by spectrophotometer (BEL ${ }^{\circledR}$ SP 1105 , Italy) reading at a wavelength of $595 \mathrm{~nm}$. It was considered as a keratinase unit (UK), an increase of 0.01 on the absorbance reading when compared with the control (buffer solution pH 8.0 and Keratin Azure only) (Apodaca et al., 1990).

For the elastase production, the supernatant was again obtained after centrifugation, and $1 \mathrm{ml}$ was mixed to $2 \mathrm{ml}$ of 10 $\mathrm{mM}$ phosphate buffer ( $\mathrm{pH}$ 7.0) and $20 \mathrm{mg}$ of Elastin Congo-Red (SIGMA ${ }^{\circledR}$ ). After $2 \mathrm{~h}$ at $37^{\circ} \mathrm{C}$, and centrifugation at 6,000 rpm for $10 \mathrm{~min}$, the elastin degradation was quantified by spectrophotometer readings at a wavelength of $495 \mathrm{~nm}$. It was considered as an elastase unit (UE), an increase of 0.1 of the absorbance when compared to the control (phosphate buffer $\mathrm{pH}$ 7.0 and Elastin Congo-Red only) (Rust et al., 1994).

To verify the collagenase production, $0.2 \mathrm{ml}$ of the supernatant obtained after centrifugation at 6,000 rpm for $10 \mathrm{~min}$ was mixed with $0.2 \mathrm{ml}$ of a suspension containing $1.0 \mathrm{mmol} / \mathrm{L}$ synthetic peptide [PZ- Pro-Leu-Gly-Pro-d-Arg] (SIGMA ${ }^{\circledR}$ ), prepared with $0.1 \mathrm{~mol} / \mathrm{L}$ of tris- $\mathrm{HCl}$ buffer $(\mathrm{pH} 7.2)$ and $1.6 \mathrm{ml}$ tris- $\mathrm{HCl}$ buffer, followed by one-hour incubation at $37{ }^{\circ} \mathrm{C}$ and another centrifugation round (Viani et al., 2001; da Silva et al, 2005). Peptide degradation and [PZ-Pro-Leu] production were measured by spectrophotometer at a wavelength of $320 \mathrm{~nm}$. The increase of 0.1 in absorbance when compared to the control ( $0.4 \mathrm{ml}$ buffer and $0.2 \mathrm{ml}$ substrate only) was considered a collagenase unit (UC) (Söderling \& Paunio, 1981; Chakraborty \& Chandra, 1986).

The evaluation of lipase and DNase production was based on halo degradation tests in Petri dishes containing the substrate for each enzyme. Disposable inoculation loops $(1 \mu \mathrm{l})$ were used to place the inoculum in the center of Petri dishes $(90$ x $15 \mathrm{~mm}$ ) containing culture medium for lipase (1000 ml distilled water; $10 \mathrm{~g}$ peptone; $5 \mathrm{~g} \mathrm{NaCl} ; 0.1 \mathrm{~g} \mathrm{CaCl}_{2} ; 20 \mathrm{~g}$ agar-agar; $10 \mathrm{ml}$ Tween $20-\mathrm{pH}$ 5.5) and DNase (DNase Test Agar, BD ${ }^{\circledR}$, France) production tests. In both cases, cultures were incubated at $25^{\circ} \mathrm{C}$ for 15 days.

Strains were considered positive for lipase production when there was a halo degradation or the precipitation of salts around the colony. The DNase reading was also based on the halo formation, as a result of substrate degradation. However, it was necessary to add $5 \mathrm{~N}$ hydrochloric acid solution around the colonies, reading after $10 \mathrm{~min}$. The enzymatic activities were determined by the ratio between the colony diameter and the degradation halo diameter (PzL and PzD) (Price, et al., 1982).

For the gelatinase production, a dermatophyte inoculum was stabbed using a disposable inoculation loop (1 $\mu \mathrm{l})$ in a tube containing $5 \mathrm{ml}$ gelatinase detection medium (1000 ml distilled water; $5 \mathrm{~g}$ peptone; $3 \mathrm{~g}$ extract meat; $120 \mathrm{~g}$ gelatin $-\mathrm{pH}$ 
7.1). The tubes were incubated at $25{ }^{\circ} \mathrm{C}$ for seven days and placed in a refrigerated temperature for 10 min before reading, avoiding false-positive results. Gelatinase production was confirmed when liquefaction of the culture medium was observed. A positive Staphylococcus aureus strain was used as the control.

The qualitative and quantitative descriptive analyses were carried out by the software BioEstat ${ }^{\circledR}$ 5.0. The data normality was assessed by the Shapiro-Wilk test, and the Mann-Whitney test $(\alpha=0.05)$ was implemented to compare data between clinical and environmental groups.

\section{Results and Discussion}

There was a significant statistical difference in the collagenase and DNase production between environmental and clinical dermatophytes isolates. However, there was no significant statistical difference in the production of keratinase, elastase, lipase, and gelatinase between those types of samples. All dermatophyte isolates, whether of clinical or soil origin, produced keratinase, elastase (some isolates were not tested as a result of substrate scarcity) and collagenase, while there was no production of DNase, lipase, and gelatinase by some isolates (Table 1 and 2).

Table 1. Data from environmental samples and production of virulence factors.

\begin{tabular}{|c|c|c|c|c|c|c|c|c|}
\hline \multicolumn{9}{|c|}{ Virulence factors of soil dermatophytes isolates } \\
\hline Sample & Locality & Species & UK & $\mathbf{U E}$ & $\mathbf{U C}$ & PzD & PzL & G \\
\hline S1 & Viçosa-MG & N. gypsea & 8.5 & 2.09 & 4.9 & 1 & 0.5964 & + \\
\hline S2 & São João Del Rei-MG & N. gypsea & 1.4 & 0.79 & 3.83 & 1 & 0.7256 & + \\
\hline S3 & Lavrinhas-SP (Cattle corral) & N. gypsea & 1.8 & 0.5 & 4.05 & 1 & 0.2995 & + \\
\hline S4 & São Luís-MA & N. gypsea & 1.4 & 0.4 & 4.94 & 1 & 1 & + \\
\hline S5 & Tibau do Sul-RN & N. gypsea & 2.5 & $*$ & 4.82 & 1 & 0.8418 & + \\
\hline S6 & Seropédica-RJ (HVGA-UFRRJ) & N. gypsea & 1.5 & 2.94 & 4.91 & 1 & 0.8887 & + \\
\hline S7 & Seropédica-RJ (Pig farming-UFRRJ) & N. gypsea & 1.8 & 5.05 & 4.92 & 1 & 0.7615 & + \\
\hline S8 & Seropédica-RJ (Rabbit farm-CTUR I) & N. gypsea & 1.2 & 0.2 & 4.93 & 1 & 0.7898 & + \\
\hline S9 & Búzios-RJ (Sample 1) & N. gypsea & 1.4 & 0.72 & 4.87 & 1 & 0.8857 & + \\
\hline S10 & Búzios-RJ (Sample 2) & N. gypsea & 1.5 & 0.8 & 5.03 & 1 & 0.7803 & + \\
\hline S11 & Seropédica-RJ (Bystreet 16) & N. gypsea & 1 & 1.2 & 4.97 & 1 & 0.6354 & + \\
\hline S12 & Lavrinhas-SP (Dog kennel) & N. gypsea & 2.2 & 2.82 & 5 & 1 & 0.6214 & + \\
\hline S13 & Seropédica-RJ (Rabbit farm -CTUR II) & N. gypsea & 2 & $*$ & 5.07 & 1 & 0.8298 & - \\
\hline S14 & Seropédica-RJ (Goat farm -UFRRJ) & N. gypsea & 1.8 & 0.15 & 5.06 & 1 & 0.8514 & + \\
\hline S15 & Seropédica-RJ (Cattle corral -UFRRJ) & N. gypsea & 1.6 & $*$ & 4.95 & 1 & 0.85 & + \\
\hline S16 & Manaus-AM (Dessana Tribe) & N. gypsea & 2.3 & $*$ & 4.95 & 1 & 0.8633 & + \\
\hline S17 & Jataí-GO & N. gypsea & 2 & $*$ & 5.02 & 1 & 0.8083 & + \\
\hline S18 & Vitória-ES (Sample 1) & N. gypsea & 2.3 & $*$ & 4.97 & 1 & 0.8201 & + \\
\hline S19 & Lavrinhas-SP (Vegetable garden) & N. gypsea & 2.4 & $*$ & 4.82 & 1 & 0.5837 & + \\
\hline S20 & Cruzeiro-SP (Garden) & N. gypsea & 2.6 & $*$ & 5.22 & 1 & 0.8597 & + \\
\hline S21 & Vitória-ES (Sample 2) & N. gypsea & 2.4 & $*$ & 4.87 & 1 & 0.7439 & + \\
\hline S22 & Vitória-ES (Sample 3) & N. gypsea & 2.4 & $*$ & 4.88 & 1 & 0.6753 & + \\
\hline S23 & Vitória-ES (Sample 4) & N. gypsea & 2.7 & $*$ & 5.15 & 1 & 0.7833 & + \\
\hline S24 & Brasília (Residential area) & N. gypsea & 1.5 & $*$ & 5.11 & 1 & 0.7907 & + \\
\hline S25 & Engenheiro Navarro-MG (Urban area) & N. gypsea & 2.1 & $*$ & 5.06 & 1 & 0.8222 & + \\
\hline S26 & Lavrinhas-SP (Chicken farm) & N. nana & 1.1 & 0.7 & 4.9 & 0.8608 & 1 & + \\
\hline S27 & Búzios-RJ (Sample 3) & Trichophyton sp. & 3 & $*$ & 5.28 & 0.9227 & 0.9598 & + \\
\hline
\end{tabular}




\begin{tabular}{cccccccccc} 
S28 & Rio de Janeiro-RJ/Padre Miguel & Trichophyton sp. & 1.3 & $*$ & 4.97 & 0.9046 & 0.4105 & + \\
S29 & Seropédica-RJ (Rabbit farm-UFRRJ) & Trichophyton sp. & 1.8 & $*$ & 5.01 & 0.8003 & 0.805 & - \\
S30 & Engenheiro Navarro-MG (Farm) & Trichophyton sp. & 2.1 & $*$ & 5.06 & 0.7553 & 0.3879 & + \\
\hline Average & & & 2.1 & 1.412 & 4.917 & 0.9748 & 0.7557
\end{tabular}

UK-Keratinase unit; UE-Elastase unit; UC-Collagenase unit; PzD-DNase Pz Ratio; PzL-Lipase Pz Ratio; G-Gelatinase; *-Not tested / Source: personal archive. Source: Authors.

Table 2. Data from clinical samples and production of virulence factors.

\begin{tabular}{|c|c|c|c|c|c|c|c|c|}
\hline \multicolumn{9}{|c|}{ Virulence factors of isolates obtained from animals with dermatophytosis } \\
\hline Sample & Animal species & Species & UK & UE & UC & PzD & PzL & G \\
\hline $\mathrm{C} 1$ & Canis lupus familiaris & Microsporum canis & 1.8 & 0 & 4.86 & 0.846 & 0.5806 & + \\
\hline $\mathrm{C} 2$ & Felis catus & Microsporum canis & 2.4 & 8.1 & 4.9 & 0.8318 & 0.6796 & + \\
\hline $\mathrm{C} 3$ & Felis catus & Microsporum canis & 2.4 & 1.33 & 4.89 & 0.8453 & 1 & + \\
\hline $\mathrm{C} 4$ & Felis catus & Microsporum canis & 2.4 & 2.32 & 4.87 & 0.7697 & 0.8065 & + \\
\hline C5 & Canis lupus familiaris & Microsporum canis & 1 & 0.38 & 4.84 & 0.8571 & 0.7243 & - \\
\hline C6 & Felis catus & Microsporum canis & 4.3 & 1.21 & 4.86 & 0.7146 & 0.6951 & - \\
\hline $\mathrm{C} 7$ & Felis catus & Microsporum canis & 1.9 & 0.8 & 4.91 & 0.6141 & 0.5245 & - \\
\hline $\mathrm{C} 8$ & Canis lupus familiaris & Microsporum canis & 1.2 & 0.16 & 4.89 & 0.6312 & 0.6282 & - \\
\hline C9 & Felis catus & Microsporum canis & 1.6 & 3.93 & 4.87 & 0.7233 & 1 & + \\
\hline $\mathrm{C} 10$ & Felis catus & Microsporum canis & 1.1 & $*$ & 5.03 & 0.7859 & 0.6616 & + \\
\hline $\mathrm{C} 11$ & Felis catus & Microsporum canis & 1.5 & $*$ & 4.87 & 0.8557 & 0.6354 & + \\
\hline $\mathrm{C} 12$ & Canis lupus familiaris & N.gypsea & 4.1 & $*$ & 4.84 & 0.8777 & 1 & + \\
\hline $\mathrm{C} 13$ & Canis lupus familiaris & N.gypsea & 1.4 & 3.44 & 4.79 & 1 & 0.719 & + \\
\hline $\mathrm{C} 14$ & Canis lupus familiaris & N.gypsea & 1 & 1.33 & 4.82 & 1 & 0.6732 & + \\
\hline $\mathrm{C} 15$ & Felis catus & N.gypsea & 1.5 & 1.74 & 4.84 & 1 & 0.8947 & + \\
\hline $\mathrm{C} 16$ & Felis catus & N.gypsea & 0.5 & $*$ & 4.85 & 0.8828 & 0.7705 & + \\
\hline $\mathrm{C} 17$ & Canis lupus familiaris & N.gypsea & 2.3 & $*$ & 4.96 & 1 & 0.8266 & + \\
\hline $\mathrm{C} 18$ & Canis lupus familiaris & N.gypsea & 1.3 & $*$ & 4.9 & 0.5252 & 0.7752 & + \\
\hline $\mathrm{C} 19$ & Canis lupus familiaris & N. nana & 1.7 & 3.78 & 4.84 & 0.871 & 0.7741 & + \\
\hline $\mathrm{C} 20$ & Canis lupus familiaris & N. nana & 2.2 & * & 4.95 & 0.9378 & 0.7634 & + \\
\hline $\mathrm{C} 21$ & Oryctolagus cuniculus & Trichophyton mentagrophytes & 2.6 & 0.83 & 4.83 & 0.8991 & 0.691 & + \\
\hline $\mathrm{C} 22$ & Canis lupus familiaris & Trichophyton mentagrophytes & 1.4 & 1.94 & 4.85 & 0.8506 & 0.5292 & + \\
\hline $\mathrm{C} 23$ & Canis lupus familiaris & Trichophyton mentagrophytes & 2.4 & 3.72 & 4.86 & 0.7291 & 0.934 & + \\
\hline $\mathrm{C} 24$ & Cavia porcellus & Trichophyton mentagrophytes & 1.7 & 3.17 & 4.92 & 0.8825 & 0.8174 & + \\
\hline $\mathrm{C} 25$ & Canis lupus familiaris & Trichophyton sp. & 1.5 & 0.29 & 4.94 & 0.6976 & 0.8677 & + \\
\hline $\mathrm{C} 26$ & Felis catus & Trichophyton sp. & 2.4 & 0.93 & 4.9 & 0.85 & 0.9185 & + \\
\hline $\mathrm{C} 27$ & Canis lupus familiaris & Trichophyton sp. & 1 & 1.62 & 4.91 & 0.9387 & 1 & - \\
\hline $\mathrm{C} 28$ & Felis catus & Trichophyton sp. & 1.8 & 0.04 & 4.9 & 0.5617 & 0.7578 & - \\
\hline $\mathrm{C} 29$ & Canis lupus familiaris & Trichophyton sp. & 1.6 & 0.96 & 4.83 & 0.6655 & 1 & + \\
\hline $\mathrm{C} 30$ & Felis catus & Trichophyton sp. & 2.9 & $*$ & 5.13 & 0.8413 & 0.6289 & - \\
\hline Average & & & 1.89 & 1.91 & 4.8883 & 0.8162 & 0.7759 & \\
\hline
\end{tabular}

UK-Keratinase unit; UE-Elastase unit; UC-Collagenase unit; PzD-DNase Pz Ratio; PzL-Lipase Pz Ratio; G-Gelatinase; *-Not tested / Source: personal archive. Source: Authors. 
The fact that keratin is a primordial substrate for dermatophytes explains the keratinase production by all isolates. Also, as the soil is a rich reservoir of residual keratin of humans and animals, the similarity of UK production by groups of clinical and environmental isolates is justified. This large deposit of keratin in the soil shows that a living host is not essential for the fungal survival and that it easily finds substrates in different environments. Samples with keratinase production considerably above the average had the enzymatic test repeated, confirming the disparate data. This shows the high potential of enzymatic production of these isolates, being a sample of $M$. canis (C6) and two samples of $N$. gypsea (C12 and S1). The soil sample (S1) may come from a location with a high concentration of keratin, which would explain this increased production, while the clinical samples (C6 and C12) may originate in more severe cases of dermatophytosis. Cafarchia et al. (2012), however, found no differences in the keratinase production by dermatophytes isolates from symptomatic and asymptomatic animals, which presupposes the non-correlation between this enzymatic production and the occurrence and severity of cutaneous lesions. On the other hand, another study showed that high levels of this enzyme can be associated to the appearance of lesions, since they reported a significant difference in the enzymatic production of samples from symptomatic and asymptomatic animals (Gnat et al., 2018).

The number of UE produced was the one with the highest variation coefficient among the analyzed factors, with nonproducing isolates and isolates with a high production capacity of this enzyme. Only the isolate C1 (M. canis) was nonproducer, with two outliers, $\mathrm{C} 2$ and S7, which showed production considerably above the average. The species $M$. canis presented the major variation of production, from the absence of enzymatic production to outlier of overproduction. This suggests the involvement of this virulence factor in some specific dermatophytosis stages, even though it is apparently not essential for the development of fungi throughout the infectious process.

The production of elastase by all our soil isolates may be related to the presence of flaking residues and other decomposing biological materials on the soil. Elastin is still a constituent of deeper organism structures, such as ligaments and blood vessels, which justifies more severe and even atypical acute pictures of dermatophytosis, mainly caused by $N$. gypsea and T. mentagrophytes. In the present study, those species showed a potent elastase production, when compared with other species also considered.

The fact that collagen is the most abundant protein in the mammalian organism, may explain the large production of this enzyme by the isolates. As dermatophytosis is a superficial mycosis, the supply of collagen on the surface of living animals tends to be less than the amount found in the soil, where decomposing organisms present other sources of this protein to dermatophytes without any resistance nor immunological response, which could justify the greater production by environmental isolates.

Few studies have so far analyzed the production of collagenase by dermatophytes. Most of them on the degradation of gelatin, a product of partial hydrolysis of collagen. The higher production of our environmental isolates shows that dermatophytes produce this enzyme even when they are not growing on living organisms, which suggests that collagenase may not be directly involved in the appearance of dermatophytosis lesions, or specific stages of the disease.

The fact that none of the soil isolates of $N$. gypsea produced DNase, as well as some clinical isolates of this species, suggests that this enzyme may be directly related to specific stages (initial or advanced) of dermatophytosis, and its participation is even more likely at the beginning of the disease, as suggested by Cafarchia et al. (2012). These authors found a higher level of DNase in isolates of $M$. canis from asymptomatic animals, supporting the hypothesis of this enzyme role mainly in the early stages of the disease. Sharifzadeh et al. (2016) point out that the production of DNase is related to chronic cases of dermatophytosis, whereas isolates from acute cases tend to be weak secretors of this enzyme, such as isolates of $N$. gypsea (species related to acute cases of dermatophytosis) in the present study. 
Among the clinical isolates, there is a pattern of production, with strong fungi not producing DNase, which requires a better investigation of the characteristics of patients in order to obtain this correlation with the chronicity of dermatophytosis. What can be said is that all samples were collected from animals with lesions of dermatophytosis. Thus, this enzyme may be related to symptomatic cases.

Only seven isolates did not produce lipase, showing the production uniformity between the groups, and the absence of outliers in the results. Non-producing isolates, both clinical and environmental, are from different species, such as $M$. canis, $N$. gypsea, N. nana and Thichophyton spp., which shows that there is no correlation between enzymatic production and the species of dermatophyte, since other similar isolates were producers.

Hellgrem \& Vincent $(1980 ; 1981)$ report the production of lipase by isolates of M. canis, T. rubrum, T. mentagrophytes, and Epidermophyton floccosum, justifying this found by the need of the fungi to cross the lipid barrier present at the keratinized tissues of people and animals. It can also explain the production of lipase by environmental isolates, where the flaking tissue present in the soil tends to have lipid traces. Thus, the greatest action of this enzyme is assumed, mainly in the early stages of dermatophytosis.

Seven clinical dermatophyte isolates did not produce gelatinase, while only two environmental isolates did not produce this enzyme. As gelatine is the result of partial hydrolysis of collagen, it is assumed that all isolates capable of degrading collagen are capable of effectively liquefying the culture media containing gelatine, which did not occur. This fact can be explained by the different techniques used to verify the production of these enzymes, where spectrophotometry may have been a more sensitive and effective method for readings when compared to the liquefaction of the substrate in test tubes.

Jacobs \& Lorincz (1957) were already looking for information about the relationship between dermatophytes and gelatin, showing that culture media containing $5 \%$ of gelatin favor the growth of dermatophytes, but that concentrations above $30 \%$ inhibit the development of these fungi. They raised the hypothesis that this concentration can maintain the balance between host and dermatophyte, since $70 \%$ of the healthy collagen of living beings is water, similar to the inhibitory culture medium. This theory has not been confirmed yet. In addition, this work corroborates our data, where most dermatophytes were able to degrade this substrate.

\section{Conclusion}

Considering the analysis carried out with dermatophytes isolated from the soil and isolated from the clinical origin, the results show the same expression of factors associated with virulence, making it possible, therefore, that all strains have the capacity to promote dermatophytosis. Since this is an in vitro analysis, it is necessary to consider other aspects related to the installation of the agent, such as breaking the natural barriers, host immunity, etc.

Regarding the techniques used to detect enzymatic production, the technique that uses the Pz calculation (the relationship between colony diameters and colony diameter plus the formed halo) is practical in detecting enzymatic activity, but, unlike analysis by spectrophotometry, it is imprecise to quantify its concentration. Spectrophotometric analysis is more accurate and has more objective reading.

We were able to verify a higher prevalence of Microsporum canis isolates among clinical isolates. Considering that the samples used for fungi isolation are from a veterinary hospital that receives animals from multiple regions, it can be inferred that this is the predominant species in clinical cases. On the other hand, the species M. gypseum (Nannizzia gypsea), known to be geophilic, is related to clinical conditions of dermatophytosis, possibly being the geophilic species with greater involvement.

It was found that geophilic dermatophytes are present in several regions of the country, although very possibly they are not present in any soil sample, as physical aspects such as sandiness, pH, compaction, as well as leaching and higher or 
lower keratin content can be limiting factors to isolations. Nannizzia gypsea was the most isolated species and it can be assumed that it is present in most regions.

Thus, this research contributes to future inquiries about epedimiological aspects of dermatophytosis, such as contagion and treatment of the disease. Future research involving these results and in vivo tests should be of great elucidation of dermatophytosis.

\section{References}

Apodaca, G., \& McKerrow, J. H. (1990). Expression of proteolytic activity by cultures of Trichophyton rubrum. Journal of Medical and Veterinary Mycology, $28(2), 159-171$

Cafarchia, C., Figueredo, L. A., Coccioli, C. et al. (2012). Enzymatic activity of Microsporum canis and Trichophyton mentagrophytes from breeding rabbits with and without skin lesions. Mycoses, 55(1), 45-9.

Chakraborty, R., \& Chandra, A. L. (1986). Purification and characterization of a streptomycete collagenase. Journal of Applied Bacteriology, 61(4), 331-7.

Cortezi, M. (2009). Isolamento de microrganismos produtores de queratinase: estudo da biodegradação da queratina oriunda de penas de abatedouro de frangos. 2009. 127 p. Tese (Doutorado em Ciências Biógicas, Microbiologia Aplicada) UNESP, Instituto de Biociências, Rio Claro, São Paulo.

Da Silva, B. C. M., Auler, M. E., Ruiz, L. D. S. et al. (2005). Trichophyton rubrum isolated from AIDS and human immunodeficiency virus-infected patients in São Paulo, Brazil: antifungal susceptibility and extracellular enzyme production. Chemotherapy, 51(1), 21-6.

De Hoog, G., Dukik, K., Monod, M. et al. (2017). Toward a novel multilocus phylogenetic taxonomy for the dermatophytes. Mycopathologia, 182(1-2), 5-31.

De Hoog, G. S., Guarro, J., Gené, J., \& Figueras, M. J. (2000). Atlas of clinical fungi. Utrecht, The Netherlands: Centraalbureau voor Schimmelcultures.

Elavarashi, E., Kindo, A. J., \& Rangarajan, S. (2017). Enzymatic and non-enzymatic virulence activities of dermatophytes on solid media. Journal of clinical and diagnostic research: JCDR, 11(2), DC23.

Giudice, M. C., Reis-Menezes, A. A., Rittner, G. M. G. et al. (2012). Isolation of Microsporum gypseum in soil samples from different geographical regions of Brazil, evaluation of the extracellular proteolytic enzymes activities (keratinase and elastase) and molecular sequencing of selected strains. Brazilian Journal of Microbiology, 43(3), 895-902.

Gnat, S., Łagowski, D., Nowakiewicz, A., \& Zięba, P. (2018). Phenotypic characterization of enzymatic activity of clinical dermatophyte isolates from animals with and without skin lesions and humans. Journal of applied microbiology, 125(3), 700-9.

Hellgren, L., \& Vincent, J. (1980). Lipolytic activity of some dermatophytes. Journal of medical microbiology, 13(1), 155-7.

Hellgren, L., \& Vincent, J. (1981). Lipolytic activity of some dermatophytes. Journal of medical microbiology, 14(1), 347-350.

Ibrahim-Granet, O., Hernandez, F. H., Chevrier, G., \& Dupont, B. (1996). Expression of PZ-peptidases by cultures of several pathogenic fungi. Purification and characterization of a collagenase from Trichophyton schoenleinii. Journal of medical and veterinary mycology, 34(2), 83-90.

Kaplan, E., Gonca, S., Kandemir. et al. (2020). Genes encoding proteolytic enzymes fungalysin and subtilisin in dermatophytes of human and animal origin: a comparative study. Mycopathologia, 185(1), 137-144.

Koneman, E., Winn, J. R. W., Allen, S. et al. (2008). Diagnóstico microbiológico: texto e atlas colorido. Rio de Janeiro, Brazil: MEDSI.

Long, S., Carveth, H., Chang, Y. M., O'Neill, D., \& Bond, R. (2020). Isolation of dermatophytes from dogs and cats in the South of England between 1991 and 2017. Veterinary Record, 187(10), e87.

López-Martínez, R., Manzano-Gayosso, P., Mier, T. et al. (1994). Exoenzymes of dermatophytes isolated from acute and chronic tinea. Revista latinoamericana de microbiologia, 36(1), 17-20

Markey, B., Leonard, F., Archambault, M. et al. (2013). Clinical veterinary microbiology. Elsevier Health Sciences.

Meevootisom, V., \& Niederpruem, D.J. (1979). Control of exocellular proteases in dermatophytes and especially Trichophyton rubrum. Sabouraudia: Journal of Medical and Veterinary Mycology, 17(2), 91-106.

Monodi, M. (2008). Secreted proteases from dermatophytes. Mycopathologia, 166(5-6), 285.

Pontes, Z. B. V. S., Oliveira, A. C. D., Guerra, F. Q. S. et al. (2013). Distribution of dermatophytes from soils of urban and rural areas of cities of Paraiba state, Brazil. Revista do Instituto de Medicina Tropical de São Paulo, 55(6), 377-383.

Price, M. F., Wilkinson, I. D., \& GENTRY, L. O. (1982). Plate method for detection of phospholipase activity in Candida albicans. Sabouraudia: Journal of Medical and Veterinary Mycology, 20(1), 7-14.

Rippon, J. W. (1968). Extracellular collagenase from Trichophyton schoenleinii. Journal of bacteriology, 95(1), 43-6.

Rippon, J. W., \& Varadi, D. P. (1968). The elastases of pathogenic fungi and actinomycetes. Journal of Investigative Dermatology, 50(1), 54-8. 
Research, Society and Development, v. 10, n. 6, e21110615699, 2021

(CC BY 4.0) | ISSN 2525-3409 | DOI: http://dx.doi.org/10.33448/rsd-v10i6.15699

Sharma, A., Chandra, S., \& Sharma, M. (2012). Difference in keratinase activity of dermatophytes at different environmental conditions is an attribute of adaptation to parasitism. Mycoses, 55(5), 410-5.

Sharma, A. K., Negi, S., Sharma, V., \& Saxena, J. (2017). Isolation and Screening of Protease Producing Soil Fungi. Advance Pharmaceutical Journal, 2(3), $100-4$.

Siesenop, U., \& Böhm, K. H. (1995). Comparative studies on keratinase production of Trichophyton mentagrophytes strains of animal origin. Mycoses, 38(5-6), 205-9.

Söderling, E., \& Paunio, K. U. (1981). Conditions of production and properties of the collagenolytic enzymes by two Bacillus strains from dental plaque. Journal of Periodontal Research, 16(5), 513.

Taghipour, S., Abastabar, M., Piri, F. et al. (2021). Diversity of Geophilic Dermatophytes Species in the Soils of Iran; The Significant Preponderance of Nannizzia fulva. Journal of Fungi, 7(5), 345.

Uribe, M. P., \& Cardona-Castro, N. (2013). Mecanismos de adherencia e invasión de dermatofitos a la piel. CES Medicina, 27(1), 67-76.

Vanbreuseghem, R. (1952). Tecnique Biologique Pour l'isolement dês Dermatophytes du Sol. Annales de la Société Belge de Médicine Tropicale, Antwerp, $32,173-8$.

Vermout, S., Tabart, J., Baldo, A. et al. (2008). Pathogenesis of dermatophytosis. Mycopathologia, 166(5-6), 267.

Viani, F. C., Santos, J. D., Paula, C. R. et al. (2001). Production of extracellular enzymes by Microsporum canis and their role in its virulence. Medical Mycology, 39(5), 463-8. 